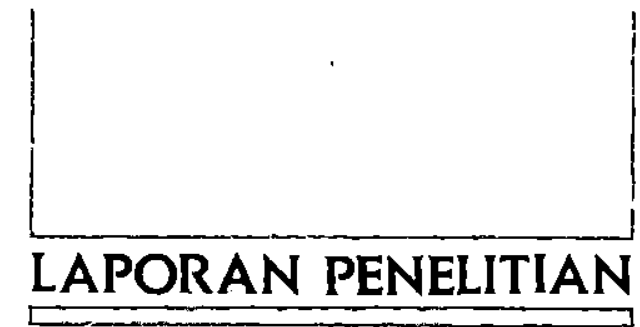

\title{
Seismic Response of Flexibly-Connected Steel Frames
}

\author{
By : Harsoyo
}

\section{Abstract}

The response of typical low-rise steel building frames designed by the "Type 2 Consctruction" method to moderate earthquakes is examined. Such frames are often identified by large girders, small columns, and semi-rigid connections. The simple methods underlying the Type 2 design approach do not permit realistic consideration of the frame response to either static or dynamic loads. In this paper, typical flexiblyconnected Type 2 frames will be analyzed for seismic resistance with the methods recommended by the 1988 Uniform Building Code. The results indicate that these Type 2 frame possess adequate strength, but may not have adequate lateral stiffness for moderate seismic loads.

\section{Introduction}

This study is an attempt to assess the performance of Type 2 steel building frames under moderate earthquake motions. Unbraced, low-rise, multi-story steel frames can be commonly found in regions of low to moderate seismic activity. This type of structure has since many years been designed as Type 2 Constructions, as authorized by Section 1.2 of the AISC Specification (1978), and more recently by the AISC. LRFD Specification (1986) under the designation $\mathrm{PR}$. The assumptions underlying Type 2 Construction (better termed "Type 2 Analysis") are simple but contradictory: beam-column connections act as pin supports under gravity loads, but show moment resistance to lateral loads. Hence, Type 2 
Construction will very often lead to slender columns and strong girders. While such an approach may result in adequate strength and ductility, it does not provide rational guidelines for stiffness assesment and sidesway control. Therefore, the major concern for such structures are the actual state of stress in the columns and the extent of sidesway that could be induced by combined lateral and gravity loads.

Recent developments (Narayanan 1985) have increased our understanding of connection respone, and modern computerbased statie and dynamic analysis methods have permitted respose prediction for flexiblyconnected frames under service and ultimate load conditions (Cook and Grestle 1987; Lionbrger and Weaver 1969; Roufaiel and Monasa 1986). These methods fall into the "Type 3 Construction" category of the AISC Spectification, which calls for rational analysis based on actual connection behavior. In this study, the respose of some realistic Type 2 multi-story steel building frames to probable earthquake motions will be evaluated by means of these methods. In particular, an attempt will be made to answer the follwing questions:

1. Will such frames remain elastic under Zone 2B level seismic forces specified in the 1988 edition of the Uniform Building code (UBC)?

2. Will their sidesways be excessive?

3. To what extent will predictions using conventional rigid-jointed frame analysis be in error?

In order to answer the above qusetions, a number of low-rise, multi-story, unbraced steel building frames which might be representative of many such struclures have been selected and modeled as flexiblyconnected frames for case studies. Based on the seismic loads and analysis procedures recommended by the 1988 UBC, the response and serviceability condition of these flexiblejointed structures under Zone 2B level seismic forces are evaluated. By tomparison with results of similar analyses of rigidjointed frames, correlation factors which might permit simpler analysis methods suitable for routine office practice, will be establised. Some dẹsign implications shall also be discussed.

\section{Steel Frame Data Base.}

The building frames selected for this study are representative of the low-rise, multi-story office, commercial, or residential buildings desigened by Type 2 methods and build with flexible girder-colomn connections. Detailed design procedures can be found in the report by Cook (1983). Fig. 1 shows the frames which range from a threestory, four-bay frame of aspect ratio (heiht/witdh) 0.45 to a four-story, two-bay frame of aspect ratio 1.2. Story heights were standardized at 12 feet $(3.66 \mathrm{~m})$, bay widths at 20 feet $(6.10 \mathrm{~m})$, and frame spacing at 25 feet $(7.62 \mathrm{~m})$. All columns were oriented for strong-axis bending, and the column feet were fixed at grade level. These frames were designed to resist service floor dead loads of $75 \mathrm{lbs} / \mathrm{ft}^{2}(3600 \mathrm{~Pa})$, live loads of $50 \mathrm{lbs} / \mathrm{ft}^{2}{ }^{2}$ $(2400 \mathrm{~Pa})$ with floor area reduction factors according to UBC. Roof dead loads were 55 $\mathrm{lbs} / \mathrm{ft} .2(2600 \mathrm{~Pa})$, live loads $30 \mathrm{lbs} / \mathrm{ft} .2$ $(1400 \mathrm{~Pa})$, without area reduction. Wind loads were taken at $30 \mathrm{lbs} / \mathrm{ft}^{2}(1400 \mathrm{~Pa})$ of vertical wall area. Moment and forces due to gravity and lateral load combinations were reducted by a factor of $3 / 4$, follwing Section 1.5.6. of AISC Specification (1978).

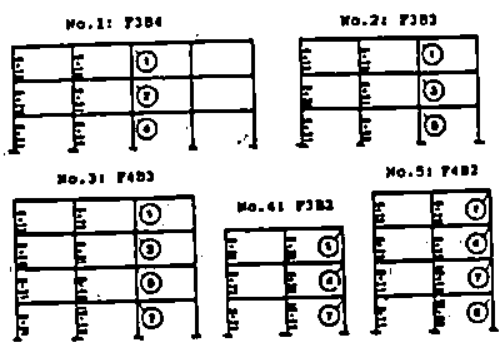

Fig. 1 - Frames selected for case studies (Cook 1983) 
Members were designed of A-36 steel, follwing the provisions of the AISC Specification (1978). A minimal column size was selected for each story, although in practice columns might well be constructed continuous over several stories. These considerations resulted in W18 X 40 girders at all floor levels; column sizes are shown in Fig. 1. 'Type 2 connections were designed follwing Part 4 of the AISC Manual (1980). Of the " simple", or "shear" connections described there, double web-angle and endplate connections were specified for the beamcolumn connections of the frames. These connections were sized by methods outlined in the report by Cook (1983) to resist the gravity load shears and the wind moments without excessive rotations, leading to the eight connections numbered 1 to 8 wich areshown in Table 1 ; their locations in the frames indicated by the numbers in Fig. 1. The Structures were assumed to be located in regions of low seismicity, and seismic forces were, therefore, not taken into consideration in the design. The performance of these structure under the specified wind load has been evaluated by Cook and Gerstle (1987).

\section{Structure Representative and Analysis.}

A general philosophy adopted in seismic resistance design is that a structurre should not suffer any structural damage in the event of a moderate earthquake which might occur during the life span of the structure; in the event of a rare and severe earthquake, structural damage may develop but the structure should remain stable without collapsing. Owing to the large deformation capability of moment-resisting - condition under very likely that the service ability condition under moderate earthquakes is of more concem than the ultimate strength. In fact, Roufaile and Monasa (1986), and Lionberger and Weaver (1969) have indicated that connection flexibility can reduce the internal moments in structural members under dynamic loads.Therefore, in this study,only the serviceability condition undermoderate earthquake loads is considered. As a result, the frames were modeled as flexiblyconnections, elasstic structures for analysis. The flexible connections were considered as rotaional springs of stiffness $k$, attached to the girder ends, as shown in Fig. 2. For such members, stiffnesses and fixed-end moments for use in direct-stiffness analysis can be calcuted by basic methods (Narayanan 1985). Their values differ from those for rigid-jointed members only by a factor which depends on the ratio of rotaional beam to connection stiffnesses, $E I / k L$, where $E I$ is the crosssectional stiffness and $L$ is the legth of the beam.

The moment-rotation curves of the eight connections listed in Table 1 were determind from the empirical formulation of Frye and Morris (1975), and are shown in Fig. 3. For the linearly-elastic analysis conducted here, the stiffneses $k$ of these connections, as shown in Table 1, were approximated by the straight lines also shown in Fig. 3.

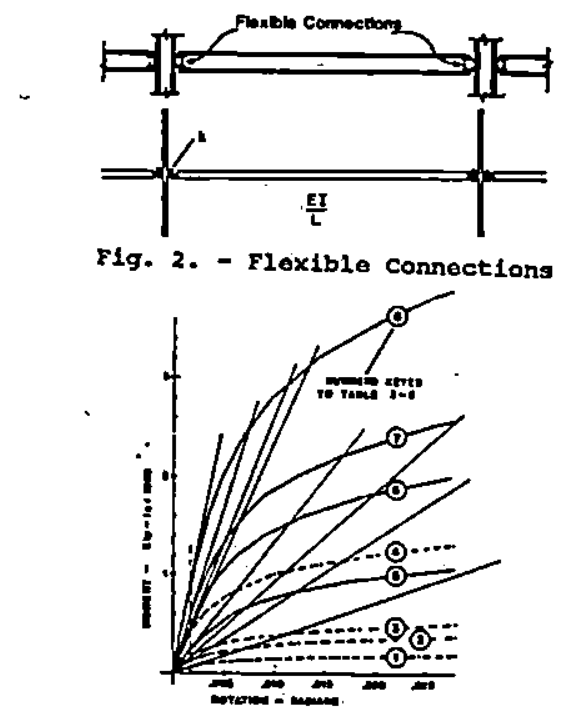

Fig. 3. - Moment-Rotation Curves for TYpe 2 Connections (Cook 1983) 


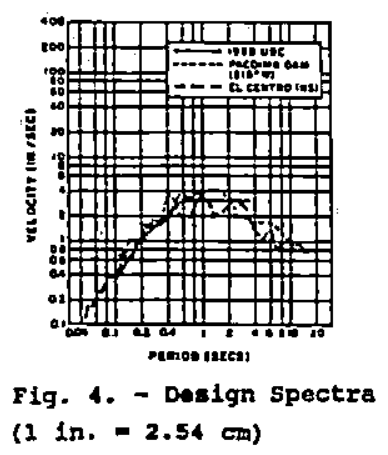

Tabla 1. Type 2 connection

( $1 \mathrm{in.}=2.54 \mathrm{~cm} 1 \mathrm{ktp}=4.45 \mathrm{kN}$ )

\begin{tabular}{|c|c|c|c|c|}
\hline concosizason & $\mathbf{m I}$ & $\begin{array}{l}\text { riognss } \\
\text { (iif.) }\end{array}$ & 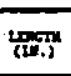 & 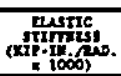 \\
\hline & 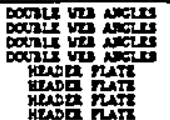 & 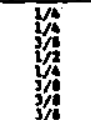 & $\begin{array}{l}12 \\
10 \\
10 \\
12 \\
\vdots \\
10 \\
12\end{array}$ & 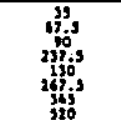 \\
\hline
\end{tabular}

Program ETABS (Wilson, Hollings, and Dovey 1979) was used for the static and dynamic analyses of these frames. In order to capture the effects of the flexible connections, this program had to be modified by replacing the conventional rigidly-connected beam stiffnesses with those for the corresponding flexibly-connected beams. The only additional input data required were the appropriate connection stiffnesses for each beam, of values shown in Table 1 . Three types of analysis were conducted in this study. The first is the static analysis based on the equivalent lateral loads specified for Seismic Zone 2B by the 1988 UBC. The second is the response spectrum analysis based on the following elastic design spectra : (i) the UBC response spectrum (for Soil Type 2) scaled to a level equivalent to that of Zone $2 B$; (ii) the response spectrum of the NS component of the $1940 \mathrm{El}$ Centro ground motion scaled approximately to the same level as the previous one; and (iii) the spectrum of the $S 15^{\circ} \mathrm{W}$ component of the Pacoima Dam record with the amplitude scaled approximately to the same level as the previous two. For the last two, damping was assumed to be $5 \%$ of the critical. The amplitude scale factors selected for the $\mathrm{EI}$ Centro and Pacoima Dam are 1/8 and 1/20, respectively. The three resulting design spectra are shown in Fig. 4. Finally, time history analysis was conducted for each frame using the El Centro ground motion with fhe same amount of damping and scale factor as the response spectrum analysis. For each frame, analyses were conducted for rigid as wèll as flexible connections.

\section{Frame Characteristics}

The natural frequencies $\omega_{n}$ and mode shapes $\phi_{n}$ of the five frames with rigid as well as flexible connections were evaluated, and the results are listed in Table 2 . In the analysis, the mass of the columns was neglected and only the floor and roof dead loads were considered. The loads were assumed to be concentrated floor load, and, thus, only the lateral story degrees of freedom were retained in the analysis. The fundamental natural periods of the frames with rigid connections are $1.41,1.38,1.54$, 1.16 , and 1.35 sec., respectively, while those with flexible connections are 1.72, 1.65, $1.85,1.35$, and $1.57 \mathrm{sec}$. It is evident that the connection flexibility increases the fundamental natural periods by 16 to $22 \%$ for the frames considered here. Moreover, as indicated in Table 2, the effect of the joint flexibility on the higher-mode frequencies is much smaller than that on the fundamental frequencies. On the other hand, the influence of the connection flexibility on the fundamental mode shapes is very small, and tends to be larger at the higher modes. More importantly, as will be shown later, the fundamental periods of these frames are considerably longer than those given by the approximate method in UBC. This is probably due to the 'strong-girder-weakcolumn design that resulted from the Type 2 approach. 
Table 2. Frequencles and Kode Shapes

\begin{tabular}{|c|c|c|c|c|c|c|c|c|c|}
\hline חuti & 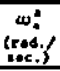 & 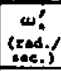 & 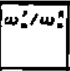 & of & A & Af & oí & 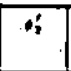 & of \\
\hline$\left(x^{2}\right)^{2}$ & $\begin{array}{l}4: 43 \\
31.67 \\
\end{array}$ & $\begin{array}{l}1: 4 \\
17.4 \\
17.4\end{array}$ & $\begin{array}{l}0.42 \\
0: y_{1}^{2} \\
0.33\end{array}$ & $\begin{array}{l}2.643 \\
0.502 \\
0.1313\end{array}$ & $\begin{array}{l}0.42 \\
-1.197 \\
-0.76\end{array}$ & $\begin{array}{c}0.102 \\
.0 .807 \\
1.306\end{array}$ & $\begin{array}{l}1.631 \\
0.173 \\
0.261\end{array}$ & $\begin{array}{l}0.190 \\
-1.203 \\
0.129\end{array}$ & $\begin{array}{l}0.133 \\
0.0 .768 \\
1.404\end{array}$ \\
\hline (г33) & $\begin{array}{l}4.53 \\
19.34 \\
19.93\end{array}$ & 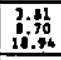 & $\begin{array}{l}0.24 \\
0.95 \\
0.93\end{array}$ & $\begin{array}{l}1.964 \\
0.726 \\
0.264\end{array}$ & 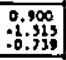 & $\begin{array}{l}0.047 \\
0.47 \\
i .67\end{array}$ & $\begin{array}{l}10.945 \\
0.735 \\
0.246\end{array}$ & 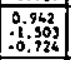 & $\begin{array}{l}0.22 \\
-0.751 \\
1.060\end{array}$ \\
\hline$\left(r^{3}(3 s)\right.$ & 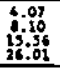 & $\begin{array}{l}3.40 \\
3.23 \\
16.11 \\
25.21\end{array}$ & 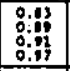 & $\begin{array}{l}1.710 \\
0.900 \\
0.100 \\
0.206\end{array}$ & 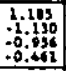 & $\begin{array}{l}0.201 \\
0.1 .43 \\
1.074 \\
0.760 \\
\end{array}$ & 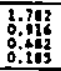 & 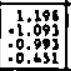 & 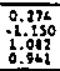 \\
\hline (เมื2) & 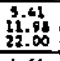 & $\begin{array}{r}6.63 \\
10.4 \\
21.41 \\
4\end{array}$ & $\begin{array}{l}0.06 \\
0.97 \\
0.7\end{array}$ & $\begin{array}{l}2.219 \\
3.170 \\
0.416 \\
\end{array}$ & $\begin{array}{r}1.47 \\
-1.97 \\
0.907 \\
\end{array}$ & $\begin{array}{l}0.161 \\
8.096 \\
2.036 \\
\end{array}$ & $\begin{array}{l}2.250 \\
1.120 \\
0.132 \\
0.12\end{array}$ & $\begin{array}{l}1,372 \\
0.710 \\
0,906 \\
\end{array}$ & $\begin{array}{l}0.193 \\
8.970 \\
2.066 \\
\end{array}$ \\
\hline (ríl1) & $\begin{array}{l}8.46 \\
10.26 \\
17.89 \\
28: 60\end{array}$ & 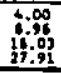 & $\begin{array}{l}0.44 \\
0: 47 \\
0.96\end{array}$ & $\begin{array}{l}1.140 \\
1: 240 \\
0: 313 \\
0.313\end{array}$ & 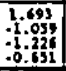 & 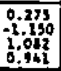 & $\begin{array}{l}2.022 \\
1.225 \\
0.2102 \\
0.277\end{array}$ & 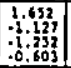 & $\begin{array}{c}0.452 \\
-1.470 \\
1.271 \\
1.168\end{array}$ \\
\hline
\end{tabular}

\section{Analysis Results}

The maximum displacement responses obtained from the UBC static load, response spectrum, and time history analyses are summarized in Table 3. The equivalet static loads for Seismic Zone 2B were determined by letting $Z=0.2, I=1$ and $S=1.5$. The fundamental natural periods of the frames, which were estimated with Method A in Section 2312 (e) of the UBC (1988), are 0.51 sec. for the three-story frames and $0.64 \mathrm{sec}$. for the four-story frames. These values correspond to the acceleration-dominated region of the UBC design spectrum (see Fig. 4), and, therefore, lead to large design load. For the response spectrum analysis, the fundamental periods calculated by ETABS were used. They are in the velocity-dominated region of the UBC spectrum. Therefore, as can be observed from Table 3 , the displacement responses obtained from the static analysis are much larger than those from the response spectrum analysis. The results obtained from the three different spectra are very consistent. Owing to the local variation of the actual earthquake spectra, the results from the UBC spectrum are slightly lower than those from the Pacoima Dam spectrum, but slightly higher than those from the El Centro spectrum. The response from the time history analysis agrees very well with the spectrum analysis, while the latter tends to be slightly more conservative.

Table 3. Displacement Envelopes (1) 1n. $=2.54 \mathrm{~cm}$ )

\begin{tabular}{|c|c|c|c|c|c|c|c|c|c|c|}
\hline \multirow[b]{2}{*}{ Faxix } & \multicolumn{2}{|c|}{ STATIC עac Las } & \multicolumn{2}{|c|}{$\begin{array}{c}\text { ybe } \\
\text { otstex } \\
\text { stection }\end{array}$} & \multicolumn{2}{|c|}{ 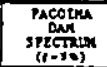 } & \multicolumn{2}{|c|}{ 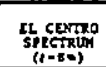 } & \multicolumn{2}{|c|}{ 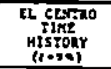 } \\
\hline & (in.) & $\frac{u_{-4}^{\prime}}{u=x}$ & (ln.). & $\frac{u^{\prime}}{4 \pm . .1}$ & (In,) & $\frac{0 . .1}{4 ! .4}$ & (In.) & to.1 & (in.) & $\frac{2 ! .1}{6 ! .1}$ \\
\hline (r) ${ }^{2}$ Bs) & $\begin{array}{l}4.62 \\
2.26 \\
0.17\end{array}$ & $\begin{array}{l}2.41 \\
1.31 \\
1.26\end{array}$ & $\begin{array}{l}1.19 \\
0: 61 \\
0.23\end{array}$ & $\begin{array}{l}1.22 \\
1: 34 \\
i .11 \\
\end{array}$ & $\begin{array}{l}1.31 \\
0.4 \\
0.24\end{array}$ & $\begin{array}{l}1.09 \\
1: 11 \\
0.04\end{array}$ & $\begin{array}{l}1: 02 \\
0.31 \\
0.23\end{array}$ & $\begin{array}{l}1.39 \\
1.34 \\
1.12\end{array}$ & $\begin{array}{l}0.97 \\
0.63 \\
0.17\end{array}$ & $\begin{array}{l}1.42 \\
1: 34 \\
1.03\end{array}$ \\
\hline$\left(\right.$ r $^{2} 3^{2}$ & $\begin{array}{l}5.14 \\
0.66\end{array}$ & $\begin{array}{l}1.42 \\
1.46 \\
1.28\end{array}$ & $\begin{array}{l}1.20 \\
0.33 \\
0.10\end{array}$ & $\begin{array}{l}1.26 \\
1.27 \\
1.13\end{array}$ & $\begin{array}{l}1.21 \\
0.53\end{array}$ & $\begin{array}{l}1.06 \\
1.02\end{array}$ & $\begin{array}{l}0.93 \\
0.45 \\
0.10\end{array}$ & $\begin{array}{l}1.30 \\
\frac{1}{1.23} \\
1.12\end{array}$ & $\begin{array}{l}0.93 \\
0.42 \\
0.13\end{array}$ & $\begin{array}{l}1.46 \\
1.30 \\
1.01\end{array}$ \\
\hline ( $\left.\mathrm{F}^{3} \mathbf{s}^{3}\right)$ & $\begin{array}{l}5.40 \\
3.09 \\
0.67 \\
0.67\end{array}$ & $\begin{array}{l}1.63 \\
1.47 \\
1.27 \\
\end{array}$ & $\begin{array}{l}1.36 \\
0.73 \\
0: 42 \\
0.16\end{array}$ & $\begin{array}{l}1.11 \\
1.17 \\
0.06 \\
0.06\end{array}$ & $\begin{array}{l}1.49 \\
0.74 \\
0.19\end{array}$ & $\begin{array}{l}1.09 \\
1.09 \\
1.09 \\
1.01\end{array}$ & $\begin{array}{l}1.20 \\
0.67 \\
0.42 \\
0.20\end{array}$ & $\begin{array}{l}2.38 \\
1.40 \\
1.37 \\
1.61\end{array}$ & $\begin{array}{l}1.32 \\
0.37 \\
0.37 \\
0.15\end{array}$ & $\begin{array}{l}1.31 \\
1.7 \\
1.65 \\
1.69\end{array}$ \\
\hline$(f)<2$ & $\begin{array}{l}2.43 \\
1.90 \\
0.53\end{array}$ & $\begin{array}{l}1.37 \\
1.30 \\
1.26\end{array}$ & $\begin{array}{l}0.42 \\
0.47 \\
0.16\end{array}$ & $\begin{array}{l}1.13 \\
1.16\end{array}$ & $\begin{array}{l}2.18 \\
0.21\end{array}$ & $\begin{array}{l}1.10 \\
1.03 \\
1.0\end{array}$ & $\begin{array}{l}0.69 \\
0.39 \\
0.16\end{array}$ & $\begin{array}{l}0.02 \\
0.43 \\
0.71\end{array}$ & $\begin{array}{l}0.63 \\
0.41 \\
0.13\end{array}$ & $\begin{array}{l}0.16 \\
0.43 \\
0.80\end{array}$ \\
\hline$(8,12)$ & $\begin{array}{l}3.14 \\
3.43 \\
3.40 \\
0.36\end{array}$ & $\begin{array}{l}1.37 \\
1.32 \\
1.30 \\
1.20\end{array}$ & $\begin{array}{l}.13 \\
0: 11 \\
0: 41 \\
0.11\end{array}$ & $\begin{array}{l}2.17 \\
1.13 \\
1.11 \\
0.19\end{array}$ & $\begin{array}{l}1.32 \\
:: \$ 3 \\
8.13\end{array}$ & $\begin{array}{l}1.06 \\
1.14 \\
0.98\end{array}$ & $\begin{array}{l}0.96 \\
0.36 \\
0.36 \\
0.15\end{array}$ & $\begin{array}{l}1.21 \\
1.24 \\
1.20 \\
1.11\end{array}$ & $\begin{array}{l}0.93 \\
0.71 \\
0.32 \\
0.13\end{array}$ & $\begin{array}{l}1.32 \\
1.25 \\
1.33 \\
1.33\end{array}$ \\
\hline
\end{tabular}

As shown in Table 3, the rations of the peak displacements of the flexibly-connected frames, $v F_{\max }$, to those of the corresponding rigidly-connected ones, $v^{R_{\max } \text {, vary from }}$ case to case. In the static analysis, the ratios are between 1.20 and 1.51. In the UBC. spectrum analysis, they are between 0.86 and 1.34. This difference is consistent with the corresponding analysis methods. In the static analysis, deflection is inversely proportional to the stiffness of a structure, and is, therefore, approximately inversely proportional to the square of the fundamental frequency, whereas, in the spectrum analysis, the displacement response of a structure in the velocity-dominated region is inversely proportional to the fundamental frequency.

This observation is well substantiated by the $\omega^{\mathrm{F}} / \omega^{\mathrm{R}}$ rations shown in Table 2 . The ratios obtained from the El Centro spectrum are larger than those from the UBC spectrum due to the additional variation of the former spectrum curve in that frequency range. However, those from the Pacoima Dam are lower. In the time history analysis, the ratios are between 0.83 and 1.74 . These results indicate the significance of connection flexibility on seismic response. 
Table 4. Maximum story Drifte

\begin{tabular}{|c|c|c|c|c|c|c|c|c|}
\hline & \multicolumn{2}{|c|}{ stasic : } & \multicolumn{2}{|c|}{ 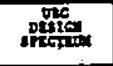 } & \multicolumn{2}{|c|}{ 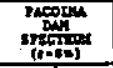 } & \multicolumn{2}{|c|}{ coctingo } \\
\hline neva & o. & 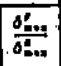 & Pós & 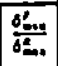 & $0_{0}^{\prime}$ & 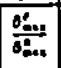 & $8 f^{\prime}$ & $\frac{\theta_{0}^{\prime}}{\partial E x}$ \\
\hline (n) & $\begin{array}{l}\because 0963 \\
: 006 \\
: 0061\end{array}$ & 1:4: & $\begin{array}{l}.0053 \\
.0073 \\
.0017\end{array}$ & 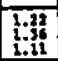 & 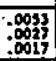 & 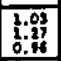 & 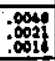 & $\begin{array}{l}1.20 \\
1: 31 \\
1.12 \\
\end{array}$ \\
\hline (nis) & $\begin{array}{l}: 0103 \\
: 0090 \\
: 0046\end{array}$ & 1.34 & $\begin{array}{l}.0056 \\
.0024 \\
.0011\end{array}$ & $\begin{array}{l}1.13 \\
\text { 1.1.12 }\end{array}$ & 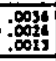 & $\begin{array}{l}7: 01 \\
\text { 1:03 } \\
\text { i.jo } \\
\end{array}$ & $\begin{array}{l}.0045 \\
0.0070 \\
00012 \\
00012\end{array}$ & i.17 \\
\hline (2032) & 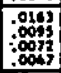 & $\begin{array}{l}1.14 \\
\text { 1.:4 } \\
1: 27 \\
\end{array}$ & 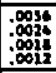 & $\begin{array}{l}1.03 \\
1.31 \\
0.13 \\
0\end{array}$ & $\begin{array}{ll}\infty \\
0 \\
0 \\
0 \\
0 \\
\infty\end{array}$ & $\begin{array}{l}1.13 \\
1: 0 \\
1: 01 \\
1.01\end{array}$ & 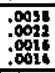 & $\begin{array}{l}133 \\
1: 37 \\
1.40\end{array}$ \\
\hline (ris) & 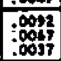 & 1.:4 & $\begin{array}{l}.027 \\
\text { o. } \\
\infty \infty 212 \\
\infty \infty 12\end{array}$ & $\begin{array}{l}1.19 \\
1.17 \\
1.11\end{array}$ & 禹典 & $\begin{array}{l}1.13 \\
1.0 \\
1.0\end{array}$ & $\begin{array}{l}.024 \\
: 0017 \\
.0012\end{array}$ & $\begin{array}{l}1.0 \\
0.4 \\
0.4\end{array}$ \\
\hline (nit) & 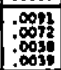 & i: & $\begin{array}{l}0017 \\
00072 \\
00013 \\
00012 \\
00012\end{array}$ & 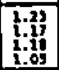 & 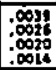 & 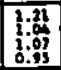 & 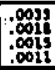 & 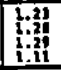 \\
\hline
\end{tabular}

Table 5. Maximum Strosens Induced by 1940 E1 Centro (I ke1 $\infty 6.89 \mathrm{MPa}$ )

\begin{tabular}{|c|c|c|c|c|c|c|}
\hline & & \multicolumn{5}{|c|}{ nuta } \\
\hline & $\operatorname{mox}$ & (n) & ( $\left.\mathbf{r}^{2} 33\right)$ & (2xis) & (r)is) & 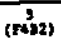 \\
\hline 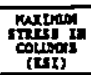 & & $\begin{array}{c}\frac{14.3}{23: 1} \\
\frac{120.1}{20.2}\end{array}$ & $\begin{array}{l}20.3 \\
31: 0\end{array}$ & $\begin{array}{l}23.5 \\
24: 0 \\
22: 3 \\
22.1\end{array}$ & $\begin{array}{l}23: 5 \\
25: 0 \\
20: 5\end{array}$ & $\begin{array}{l}23: 1 \\
34: 1 \\
33: 6\end{array}$ \\
\hline 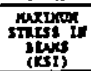 & & $3: 1$ & $\begin{array}{l}3: 3 \\
16.6\end{array}$ & $\begin{array}{l}3.5 \\
10.8 \\
10.8\end{array}$ & $\begin{array}{l}3.2 \\
16: 0\end{array}$ & $\begin{array}{l}3.2 \\
16.2 \\
11: 0\end{array}$ \\
\hline
\end{tabular}

The maximum story drift $\delta_{\text {max }}$, which is defined as the maximum relative displacement of a story divided by its height, is shown in Table 4. The UBC drift limitation for structures of such heights is 0.005 . As shown in Table 4, except for the UBC static load, which resulted in very large drifts, the drifts are marginally satisfactory in most cases, with the largest value being 0.0061 . In almost all cases, drifts tend to be a lot more significant in the upper stories than in the lower stories because of the weaker columns in the upper stories. Furthermore, it must be realized that the frames were designed for lateral wind pressure which was assumed to be uniform along the height of a structure, whereas, the lateral loads due to earthquakes are more or less proportional to the story height. The average drift over an entire structure ranges from 0.002 to 0.003 in the response spectrum and time history analyses.

The maximum stresses in the columns (without moment magnification) and beams obtained from the time history analysis are listed in Table 5. The stresses in the columns are much larger than those in the beams, but well below the 36-ksi yield limit. This indicates that story drift is most likely the predominant problem for this type of structures when subjected to larger seismic forces.

\section{Conclusions}

The results of this study indicate that the frames considered here are adequately designed for seismic forces not greater than those corresponding to UBC Seismic Zone 2B.

There is also indication that drift is very likely the controlling factor for the design of such structures. In particular, the results show that structures designed for uniform wind pressure tend to develop large disppacement drifts in the upper stories under earthquake excitation. Therefore, story drift could be a problem for Zone 2B seismic forces if the structures were designed for wind pressure less than $30 \mathrm{lbs} / \mathrm{ft}^{2}$. It is also shown that special precautions should be taken if the static analysis recommended by the 1988 UBC is used. The approcimate formula recommended by the code for estimating the fundamental period of a moment-resisting frame may not be adequate for low-rise Type 2 frames that have strong girders and weak columns, and could result in unrealistically large design loads. On the other hand, it may lead to stronger columns in a design and, thereby, reduce the story drift. Hence, further study should be conducted to clarify this issue. Finally, it has been shown that the actual displacement amplitude of a flexibly-connected frame can be $50 \%$ higher than that predicted by the dynamic analysis based the rigid-joint assumption. 


\section{Appendix-References}

Cook, N.E., Jr. (1983). "Strength and stiffness of Type 2 steel frames," Report to AISC, Dept. of Civ., Environ., and Archit. Engrg., Univ. of Colorado, Boulder, Co.

Cook, N.E., Jr., and Gerstle, K.H. (1987). "Safety of Type 2 steel frames," J. of Struct. Engrg., ASCE, Vol. 113 (7), 1444-1455.

Frye, M.J., and Morris, G.A. (1975). "Analysis of flexibly-connected steel frames," Can.J. of Civ. Engrg., 2 (3).

Lionberger, S.R., and Weaver, W., Jr. (1969).

- "Dynamic response of frames with nonrigid connections," $J$. of Engrg. Mech. Div., ASCE, 95 91), 95-114.

LRFD Specification for structural steel buildings. (1986). Amer. Inst. Steel Const., Chicago, IIl.

Manual of steel construction. (1980). Amer. Inst. Steel Const., Chicago, Ill.
Narayanan, R. (1985). Steel frame structures. "Flexibly-conected steel frames," (Chapter 7). Elsevier Applied Science Publishers, London and New York.

Roufaiel, M.S.L., and Monasa, F.F. (1986). "Seismic behavior of Unbraced steel building frames with semi-rigid connections," Proceedings, Third U.S. National Conference of Earthquake Engineering, Charleston, SC, 3, 18271838.

Specification for the design, fabrication and erection of structural steel for buildings. (1978). Amer. Inst. Steel Const., Chicago, IIl.

Uniform Building Code. (1988). International Conference of Building Officials, Whittier, $\mathrm{Ca}$.

Wilson, E.L., Hollings, J.P., and Dovey, H.H. (1975). "ETABS," Report No. EERC 75 13, Earthquake Engineering Research Center, Univ. of California, Berkeley, Ca. 
